\title{
SGLT2 Inhibitors for Treatment of Diabetic Nephropathy
}

\author{
Nasser Mikhail* \\ Endocrinology Division, David-Geffen UCLA School of Medicine, USA
}

Submission: November 13, 2019; Published: November 26, 2019

*Corresponding author: Nasser Mikhail, Chief, Endocrinology Division, Olive-View UCLA Medical Center, David-Geffen UCLA School of Medicine, 14445 Olive View Dr, Sylmar, CA91342, USA

Abstract

Background: Sodium-glucose co-transporter 2 (SGLT2) are medications approved for treatment of type 2 diabetes. Recent evidence suggests that these agents exert Reno protective effects.

Methods: Review of literature (English, French, Spanish) from January 1990 to November 10, 2019. Searching terms include sodiumglucose co-transporters 2 inhibitors (SGLT2) inhibitors, chronic kidney disease (CKD), end-stage kidney disease (ESKD). Randomized trials, meta-analysis, expert opinions and guidelines are also reviewed.

Results: The effects of canagliflozin on renal events were evaluated in patients with type 2 diabetes and albuminuric diabetic nephropathy already on renin-angiotensin (RAS) blockade. The primary outcome was a composite of the incidence of ESKD, doubling of serum creatinine, renal or cardiovascular (CV) death. Canagliflozin was associated with $30 \%$ reduction in the incidence of this primary outcome [hazard ratio (HR) $0.70,95 \% \mathrm{CI} 0.59-0.82, \mathrm{P}=0.00001)]$. Similar results were generally reported in large CV trials of canagliflozin, empagliflozin and dapagliflozin although renal events were secondary or post-hoc outcomes. Renoprotection by SGLT2 inhibitors was observed in patients with different degrees of renal function at baseline, with or without albuminuria, and taking or not RAS blockers. SGLT2 inhibitors were generally safe with drug discontinuation rates similar to placebo. Canagliflozin was tolerated in patients with eGFR $<60 \mathrm{ml} / \mathrm{min} / 1.73 \mathrm{~m} 2$. The incidence of acute renal injury was numerically less frequent with SGLT2 inhibitors compared with placebo.

Conclusions: SGLT2 inhibitors slow progression of diabetic nephropathy and should be standard of care on top of RAS blockers for renal protection in patients with type 2 diabetes. Regulatory authorities should consider allowing using canagliflozin $100 \mathrm{mg} / \mathrm{d}$ in patients with estimated glomerular filtration rate (eGFR) between $30-45 \mathrm{ml} / \mathrm{min} / 1.73 \mathrm{~m}^{2}$.

Keywords: SGLT2 inhibitors; Empagliflozin; Canagliflozin; Dapagliflozin; Renal function; Diabetes; Diabetic nephropathy

Abbreviations: SGLT2: Sodium-Glucose Co-Transporter 2; ESKD: End-Stage Kidney Disease; CKD: Chronic Kidney Disease; RAS: ReninAngiotensin; CV: Cardiovascular; HR: Hazard Ratio; RR: Relative Risk

\section{Introduction}

Chronic kidney disease (CKD) occurs in approximately $40 \%$ of patients with type 2 diabetes and contributes to approximately $50 \%$ of ESKD [1]. SGLT2 inhibitors represent a class of antidiabetic agents that decrease hyperglycemia independently of insulin by lowering the renal threshold for glucose and therefore increasing urinary excretion of glucose [2]. Several welldesigned trials suggest that the 3 SGLT2 inhibitors canagliflozin, empagliflozin, and dapagliflozin share 2 main consistent benefits: reduction in heart failure hospitalization and slowing of progression of kidney failure in patients with type 2 diabetes [3-6]. This mini review focuses on the renoprotective aspect of SGLT2 inhibitors.

\section{Clinical Trials}

In the last few years, 4 large-scale randomized trials have shown that the 3 SGLT2 inhibitors, empagliflozin, dapagliflozin, and canagliflozin have renoprotective effects that are largely independent of their anti-hyperglycemic action [36]. Overview of these 4 trials are summarized in table 1 . The most important of these trials is CREDENCE study because it is the only available large study that was specifically designed and powered to examine the effects of canagliflozin on renal events in patients with type 2 diabetes [3]. All patients in CREDENCE had established albuminuric nephropathy and already on RAS blockade [3]. Thus, the primary outcome in CREDENCE was a composite of the incidence of ESKD, doubling 
of serum creatinine, renal or CV death (Table 1) [3]. After a median follow-up of 2.62 years, the event rate of the primary outcome was $30 \%$ lower in the canagliflozin group than in the placebo group [HR 0.70, 95\% CI 0.59-0.82, P=0.00001)] (Table 1) [3]. In addition, canagliflozin effect was also significant in 2 individual components of the primary outcome, namely ESKD (HR 0.68, 95\% CI 0.54-0.68, P=0.002), and doubling of the serum creatinine level (HR 0.60, 95\% CI 0.48-0.76, P <0.001) [3]. The other 3 trials called CANVAS, DECLARE-TIMI, and EMPA-REG, were primarily designed to evaluate CV safety of canagliflozin, dapagliflozin and empagliflozin, respectively [4-6]. Renal events were not primary outcomes in these trials but were analyzed as pre-specified secondary or post-hoc outcomes (table 1) [4-6]. Nevertheless, despite some differences in the definition of renal outcomes, the results of the 4 trials are in general agreement and complementary (Table 1). In fact, a recent meta-analysis showed that renal protection was similar across the 4 trials [7]. Hence, these 3 SGLT2 inhibitors reduced relative risk (RR) of dialysis, renal transplantation, or death due to renal disease by $33 \%$ compared with placebo (RR 0.67, 95\% CI 0.52-0.86, P=0.001) [7]. In addition, the risk reduction for ESKD was 35\% (RR 0.65, 95\% CI 0.53-0.81, $\mathrm{P}=0.0001$ ) [7].

Table 1: Overview of Major Renal Trials of SGLT2 Inhibitors in Type 2 Diabetes.

\begin{tabular}{|c|c|c|c|c|}
\hline Trial & CREDENCE [3] & CANVAS [4] & DECLARE-TIMI [5] & EMPA-REG [6] \\
\hline $\begin{array}{l}\text { SGLT-2 } \\
\text { inhibitor }\end{array}$ & Canagliflozin & Canagliflozin & Dapagliflozin & Empagliflozin \\
\hline Design & $\begin{array}{l}\text { Randomized, double-blind, } \\
\text { multicenter }\end{array}$ & $\begin{array}{l}\text { Randomized, double-blind, } \\
\text { multicenter }\end{array}$ & $\begin{array}{l}\text { Randomized, double-blind, } \\
\text { multicenter }\end{array}$ & Randomized, double-blind, multicenter \\
\hline Patients & $\begin{array}{l}\mathrm{N}=4401, \text { mean age } 63 \mathrm{y} / \mathrm{o}, \\
34 \% \text { women }\end{array}$ & $\begin{array}{c}\mathrm{N}=10142, \text { mean age } 63 \mathrm{y} / \mathrm{o}, \\
35.8 \% \text { women }\end{array}$ & $\begin{array}{l}\mathrm{N}=17160, \text { mean age } 64, \\
37.5 \% \text { women }\end{array}$ & $\mathrm{N}=7020$, mean age $63,28 \%$ women \\
\hline $\begin{array}{l}\text { Baseline } \\
\text { renal func- } \\
\text { tion }\end{array}$ & $\begin{array}{l}\text { Mean eGFR; } 56.2 \mathrm{ml} / \\
\min / 1.73 \mathrm{~m}^{2} . \text { Range } \\
\text { of eGFR } 30 \text { to }<90 \mathrm{ml} / \\
\min / 1.73 \mathrm{~m}^{2} .\end{array}$ & $\begin{array}{c}\text { Mean eGFR: } 76.5 \mathrm{ml} / \mathrm{min} / 1.73 \\
\mathrm{~m}^{2} . \text { eGFR > } 30 \mathrm{ml} / \mathrm{min} / 1.73 \\
\mathrm{~m}^{2} .\end{array}$ & $\begin{array}{c}\text { Mean eGFR } 85 \mathrm{ml} / \\
\text { min/ } 1.73 \mathrm{~m}^{2} .47 .6 \% \text { of } \\
\text { patients: eGFR } \geq 90 \mathrm{ml} / \\
\text { min/ } 1.73 \mathrm{~m}^{2} .45 \% \text { of } \\
\text { patients: had eGFR } 60 \text { to }< \\
90 \mathrm{ml} / \mathrm{min} / 1.73 \mathrm{~m} 2.7 .4 \% \\
\text { of patients had eGFR }<60 / \\
\mathrm{ml} / \mathrm{min} / 1.73 \mathrm{~m}^{2} .\end{array}$ & $\begin{array}{c}\text { Mean eGFR: } 74.0 \mathrm{ml} / \mathrm{min} / \mathrm{m} 2.74 .4 \% \\
\text { of patients: eGFR } \geq 60 \mathrm{ml} / \mathrm{min} / 1.73 \mathrm{~m}^{2} . \\
17.8 \% \text { of patients: eGFR: } 45-59 \mathrm{ml} / \\
\min / 1.73 \mathrm{~m}^{2} .7 .7 \% \text { of patients: eGFR } 30 \text { - } \\
44 \mathrm{ml} / \mathrm{min} / 1.73 \mathrm{~m}^{2} .\end{array}$ \\
\hline $\begin{array}{l}\text { Proportions } \\
\text { of patients } \\
\text { with albu- } \\
\text { minuria }\end{array}$ & $100 \%$ & $30 \%$ & $7 \%$ & $11 \%$ \\
\hline $\begin{array}{l}\text { Proportions } \\
\text { of patients } \\
\text { with estab- } \\
\text { lished CV } \\
\text { disease }\end{array}$ & $50 \%$ & $65 \%$ & $40 \%$ & $100 \%$ \\
\hline Follow-up & Median $2.6 \mathrm{y}$ & Mean 188.2 wks & Median $4.2 \mathrm{y}$ & Median $3.1 \mathrm{y}$ \\
\hline $\begin{array}{l}\text { Interven- } \\
\text { tion }\end{array}$ & $\begin{array}{l}\text { Canagliflozin } 100 \mathrm{mg} / \mathrm{d} \text { vs } \\
\text { placebo }\end{array}$ & $\begin{array}{c}\text { Canagliflozin } 100 \mathrm{mg} / \mathrm{d}, 300 \\
\mathrm{mg} / \mathrm{d} \text { vs placebo }\end{array}$ & $\begin{array}{c}\text { Dapagliflozin } 10 \mathrm{mg} / \mathrm{d} \text { vs } \\
\text { placebo }\end{array}$ & $\begin{array}{c}\text { Empagliflozin } 10 \mathrm{mg} / \mathrm{d}, 25 \mathrm{mg} / \mathrm{d} \text { vs } \\
\text { placebo }\end{array}$ \\
\hline $\begin{array}{l}\text { Renal out- } \\
\text { come }\end{array}$ & $\begin{array}{l}\text { Primary outcome: com- } \\
\text { posite of end-stage renal } \\
\text { disease (dialysis, trans- } \\
\text { plantation, or sustained } \\
\text { eGFR }<15 \mathrm{ml} / \mathrm{min} / 1.73 \\
\mathrm{~m}^{2} \text { ), doubling of serum cre- } \\
\text { atinine, or death from renal } \\
\text { or cardiovascular causes }\end{array}$ & $\begin{array}{l}\text { Secondary outcome: progres- } \\
\text { sion of albuminuria ( } 30 \% \\
\text { increase and a change from } \\
\text { either normoalbuminuria to } \\
\text { micro- or macroalbuminuria } \\
\text { microalbuminuria to mac- } \\
\text { roalbuminuria. Exploratory } \\
\text { outcomes: } 1 \text {. Regression of } \\
\text { albuminuria, 2. Composite of: } \\
40 \% \text { sustained reduction in } \\
\text { eGFR, need for renal-replace- } \\
\text { ment therapy, or death from } \\
\text { renal causes. }\end{array}$ & $\begin{array}{c}\text { Secondary outcome: com- } \\
\text { posite of sustained decline } \\
\text { of a least } 40 \% \text { in eGFR to } \\
\text { less than } 60 \mathrm{ml} / \mathrm{min} / 1, .73 \\
\mathrm{~m}^{2} \text {, end-stage renal disease } \\
\text { (dialysis, transplantation, } \\
\text { or sustained GFR }<15 \mathrm{ml} / \\
\text { min } / 1.73 \mathrm{~m}^{2} \text {, or death from } \\
\text { renal or cardiovascular } \\
\text { causes. }\end{array}$ & $\begin{array}{l}\text { Secondary outcome: incident or wors- } \\
\text { ening nephropathy defined as progres- } \\
\text { sion to macroalbuminuria (urinary } \\
\text { albumin-to-creatinine ratio }>300 \mathrm{mg} \\
\text { albumin/g creatinine), doubling of } \\
\text { serum creatinine accompanied by eGFR } \\
\leq 45 \mathrm{ml} / \mathrm{min} / 1.73 \mathrm{~m}^{2} \text {, renal replacement } \\
\text { therapy, or cardiovascular death }\end{array}$ \\
\hline $\begin{array}{l}\text { Reduction } \\
\text { in renal } \\
\text { outcome. } \\
\text { Hazard } \\
\text { ratio ( } 95 \% \\
\text { confidence } \\
\text { interval) }\end{array}$ & $\begin{array}{l}0.70(0.59-0.82) \\
\quad P<0.00001\end{array}$ & $\begin{array}{l}\text { Risk reduction in composite } \\
\text { renal outcome } 0.6(0.47-0.77) \text {. } \\
\text { Risk reduction for progres- } \\
\text { sion of albuminuria } 0.73 \\
(0.67-0.79) \text {. Increased HR of } \\
\text { regression of albuminuria } 1.76 \\
(1.51-1.91) .\end{array}$ & $0.76(0.67-0.87), \mathrm{P}<0.0001$ & $0.61(0.55-0.69), \mathrm{P}<0.001$ \\
\hline
\end{tabular}




\section{Current Research in Diabetes \& Obesity Journal}

\begin{tabular}{|c|c|c|c|c|}
\hline $\begin{array}{l}\text { HR for } \\
\text { reduction } \\
\text { end-stage } \\
\text { kidney } \\
\text { disease }\end{array}$ & $0.68(0.54-0.86), \mathrm{P}<0.002$ & Not reported & $0.31(0.13-0.79), \mathrm{P}=0.013$ & $0.45(0.21-0.97, P=0.04$ \\
\hline $\begin{array}{l}\text { HR for CV } \\
\text { death }(95 \% \\
\quad \text { CI) }\end{array}$ & $0.78(0.61-1.00), P=0.05$ & $\begin{array}{c}0.87 \text { (0.72-1.06) P value not } \\
\text { significant }\end{array}$ & $0.98(0.82-1.17)$ & $0.62(0.49-0.77), \mathrm{P}<0.001$ \\
\hline $\begin{array}{l}\text { HR for } \\
\text { death from } \\
\text { any cause }\end{array}$ & $0.83(0.68-1.02)$ & $\begin{array}{c}0.87 \text { (0.74-1.01) P value not } \\
\text { significant }\end{array}$ & $0.93(0.82-1.04)$ & $0.68(0.57-0.82), \mathrm{P}<0.001$ \\
\hline $\begin{array}{l}\text { Mean } \\
\text { reduction } \\
\text { in blood } \\
\text { pressure vs } \\
\text { placebo }\end{array}$ & $\begin{array}{c}\text { **SBP }-3.3 \mathrm{mmHg}(95 \% \\
\mathrm{CI},-2.7 \text { to }-3.8) . * * \text { DBP } \\
-0.95 \mathrm{mmHg}(95 \% \text { CI }-0.6 \\
\text { to }-1.28)\end{array}$ & $\begin{array}{c}\text { SBP }-3.9 \mathrm{mmHg}(95 \% \mathrm{CI}-4.3 \\
\text { to }-3.5) . \mathrm{P}<0.001 \mathrm{DBP}-1.3 \\
(95 \% \mathrm{CI}-.1 .6 \text { to }-1.1) \mathrm{P}<0.001\end{array}$ & $\begin{array}{c}\text { SBP }-2.7 \mathrm{mmHg}(95 \% \\
\mathrm{CI}-2.4 \text { to }-3.0) \text { DBP }-0.7 \\
\mathrm{mmHg}(95 \% \mathrm{CI}, 0.6-0.9)\end{array}$ & Not reported \\
\hline $\begin{array}{l}\text { Mean } \\
\text { reduction } \\
\text { in HbA1c } \\
\text { vs placebo } \\
\text { throughout } \\
\text { the trial }\end{array}$ & $\begin{array}{c}-0.25 \%(95 \% \text { CI, } 0.20 \text { to } \\
-0.31)\end{array}$ & $\begin{array}{c}-0.58 \%(95 \% \mathrm{CI}-0.61 \text { to } \\
-0.56) . \mathrm{P}<0.001\end{array}$ & $\begin{array}{c}-0.42 \%(95 \% \text { CI }-0.40 \text { to } \\
-0.45)\end{array}$ & $\begin{array}{c}\text { At week 206, }-0.24 \% \text { ( } 95 \% \text { CI, }-0.4 \text { to } \\
-0.08) \text { [ empagloflozin } 10 \mathrm{mg} / \mathrm{d}] .-0.36 \% \\
\text { (95\% CI, }-0.51 \text { to }-0.21 \text { ) [empagliflozin } \\
25 \mathrm{mg} / \mathrm{d}] .\end{array}$ \\
\hline $\begin{array}{l}\text { Mean } \\
\text { reduction } \\
\text { in weight vs } \\
\text { placebo }\end{array}$ & $-0.8 \mathrm{~kg}(95 \% \mathrm{CI}-0.6$ to -0.9$)$ & $\begin{array}{c}-1.6 \mathrm{~kg}(95 \% \mathrm{CI}-1.7 \text { to }-1.5) . \mathrm{P} \\
<0.001\end{array}$ & $-1.8 \mathrm{~kg}(95 \% \mathrm{CI}-1.7$ to 2.0$)$ & Not reported \\
\hline
\end{tabular}

*eGFR: Estimated Glomerular Filtration Rate; **SBP: Systolic Blood Pressure; ${ }^{* * *}$ DBP: Diastolic Blood Pressure

\section{Effect of SGLT2 Inhibitors on Renal Function}

SGLT2 inhibitors slow the deterioration of renal function, as reflected by the eGFR slope overtime. The change in eGFR with SGLT2 inhibitors generally follows a characteristic pattern. Thus, while eGFR declines slowly and steadily in the placebo group, the eGFR worsens initially in the first 3 weeks to several months in the SGLT2 inhibitor group compared with placebo group. This is followed by gradual recovery in the SGLT2 inhibitor group to exhibit a slower decline in eGFR compared with the placebo group during the remaining observation time [3-6]. This pattern remains unchanged in subgroups with baseline eGFR $\geq 90 \mathrm{ml} /$ $\mathrm{min} / 1.73 \mathrm{~m} 2,60$ to $<90 \mathrm{ml} / \mathrm{min} / 1.73 \mathrm{~m}^{2}$, and $<60 \mathrm{ml} / \mathrm{min} / 1.73$ m2 [5]. In one study, after cessation of empagliflozin (median time since drug cessation was 34 days), the eGFR increased to study baseline level [6]. This finding suggests that renal changes induced by SGLT2 inhibitors may be reversible and most likely reflect functional rather than structural phenomena. The cause of this initial worsening of eGFR is not fully understood, but might be due to afferent arteriolar vasoconstriction, and subsequent decrease in intraglomerular pressure [8]. Indeed, SGLT2 inhibition increases glucose and sodium delivery to the distal renal tubule, which is sensed by the juxtaglomerular apparatus as increased glomerular perfusion [8]. This results in increased vasoconstriction of the afferent arterioles leading to reduction in intraglomerular perfusion and intraglomerular pressure. However, that effect stabilizes over time [8]. Interestingly, transient initial worsening of eGFR was also demonstrated with RAS blockers $[9,10]$. These agents also decrease intraglomerular pressure albeit through different mechanism by causing vasodilation of the efferent arteriole $[9,10]$.

\section{Effect of SGLT2 Inhibitors on Albumniuria}

Albuminuria is considered as surrogate marker for glomerular damage. Two CV trials, CANVAS and EMPA-REG reported on effects of SGLT2 inhibitors on albuminuria $[4,6]$. In CANVAS, canagliflozin was shown to decrease progression of albuminuria (defined as $30 \%$ increase in albuminuria and a change from either normalbuminuria to microalbuminuria or from microalbuminuria to macroalbuminuria) by $27 \%$ (HR 0.73, 95\% CI 0.67-0.79) [4]. In the meantime, regression of albuminuria to normoalbuminuria occurred more frequently with canagliflozin than with placebo (HR 1,70, 95\% CI 1.511.91) [4]. However, in EMPA-REG trial, the incidence of newonset albuminuria in the empagliflozin group was similar to placebo despite significant reduction in risk of doubling of serum creatinine by $44 \%$ and renal replacement therapy by $55 \%$ [6].

\section{Renoprotective Effects of SGLT2 Inhibitors in Different Patient Subgroups}

In general, the relative risk reduction by SGLT2 inhibitors in renal outcomes was similar across patient subgroups classified by demographics, baseline renal function, presence or absence of established CV disease [3-6,11], and the degree of baseline albuminuria [3,5]. Likewise, renal benefits were generally consistent across different levels of eGFR at baseline including patients entering the trials with eGFR $<45 \mathrm{ml} / \mathrm{min} / 1.73 \mathrm{~m} 2$ although the risk reduction was somewhat attenuated as 
eGFR values get lower [7]. Interestingly, the renal benefits of canagliflozin in CREDENCE trial were demonstrated on top of background RAS blockade [3]. Moreover, the renoprotection by dapagliflozin was similar whether patients were using RAS blockade or not [5]. Subgroup analysis from DECLARE TIMI trial suggests that the renoprotective effect of SGLTG2 inhibitor may be attenuated in patients taking diuretics [5]. Conversely, analysis from the EMP-REG trial showed that risk reduction in incident or worsening nephropathy occurred irrespective of use of diuretics [12].

\section{Mechanisms of Renoprotective Effects of SDLT2 Inhibitors}

Mechanisms underlying the protection of renal function by SGLT2 inhibitors are not fully understood and are currently an area of active research. Reduction in intraglomerular pressure, as mentioned above, seems one important factor [10]. Other mechanisms include reduction in the following parameters: serum uric acid, albuminuria, ambulatory blood pressure, and weight [10], and increase in erythropoietin [13]. Differences in HbA1c levels between the SGLT2 inhibitors group and placebo group were minimal and therefore unlikely to contribute to renal benefits (Table 1). In addition, glycemic efficacy of SGLT2 inhibitors decreases with decline in eGFR [14]. However, unlike HbA1c levels, reduction in blood pressure and weight by SGLT2 inhibitors are still preserved in patients with CKD [14].

\section{Cardiovascular Outcomes of SGLT2 Inhibitors}

Another consistent benefit of SGLT2 inhibitors clearly shown in large scale CV trials was reduction in hospitalization for heart failure by approximately $30 \%$ compared with placebo [15-17]. In addition, empagliflozin reduced cardiovascular death in patients with established CV disease [15]. In CREDENCE, in which CV events were secondary outcomes, there was significant reduction in heart failure hospitalization by $39 \%$ (HR $0.61,95 \% 0.47-0.80$, $\mathrm{P}<0.001$ ), and there was $22 \%$ reduction in $\mathrm{CV}$ death of marginal statistical significance (HR 0.78, 95\% CI 0.61-1.00, P =0.05) [3]. Interestingly, reduction of $\mathrm{CV}$ outcomes by canagliflozin, similar to renal outcomes, was consistent across all degrees of baseline eGFR and urine albumin/creatinine ratio [11].

\section{Safety of SGLT2 Inhibitors}

Overall, SGLT2 inhibitors were well-tolerated as reflected by rates of discontinuation due to adverse effects that were similar to placebo (Table 2). Likewise, rates of hypoglycemia, acute renal failure are either similar or less frequent than placebo. However, there are 2 adverse effects shared by members of the class of SGLT2 inhibitors. The most common adverse effect is genital fungal infections, particularly in women (Table 2). These infections are usually mild to moderate in severity and treated with anti-fungal without treatment interruption. Second, diabetic ketoacidosis occurred 2-10 times more frequently with SGLT2 inhibitors than placebo, but the absolute number of events was small (Table 2). Increased risk of lower limb amputation and fractures once reported in one large CV trial with canagliflozin [4], was not seen with empagliflozin, dapagliflozin and in the renal study of canagliflozin [3]. Acute renal injury was a concern because of early aggravation of eGFR soon after initiation of SGLT2 inhibitors as mentioned above. Yet, the incidence of acute renal injury was numerically decreased and not increased in the 4 major CV and renal trials of SGLT2 inhibitors (Table 2) [3-6]. In fact, meta-analysis of these 4 trials showed that acute renal injury was $25 \%$ less with SGLT2 inhibitors than with placebo (RR 0.75, 95\% CI 0.66-0.85, P value not reported [7].

Table 2: Safety of SGLT2 Inhibitors in Major Renal Trials Versus Placebo.

\begin{tabular}{|c|c|c|c|c|}
\hline & CREDENCE [3] & CANVAS [4] & DECLARE-TIMI [5] & EMPA-REG [6] \\
\hline $\begin{array}{l}\text { Withdrawal } \\
\text { due to adverse } \\
\text { effects }\end{array}$ & Not reported & $\begin{array}{c}\text { 35/1000-yr vs } 32.8 / 1000- \\
\text { yr, } P=0.07\end{array}$ & $\begin{array}{l}\text { Dapagliflozin } 8.1 \% \text { vs } \\
\text { placebo } 6.9 \%(P=0.01)\end{array}$ & $\begin{array}{c}\text { Empagliflozin } 17.3 \% \text { vs place- } \\
\text { bo } 19.4 \%\end{array}$ \\
\hline $\begin{array}{l}\text { Genital fungal } \\
\text { infections }\end{array}$ & $\begin{array}{c}\text { Males : canagliflozin: males: } 8.4 / 1000 \\
\text { patient-yr vs placebo 0.9/1000 pa- } \\
\text { tient-yr. }{ }^{*} \text { HR } 9.3 \text { (95\% CI, 2.8-30.6) } \\
\text { Females: canagliflozin : } 12.6 / 1000-y r \\
\text { vs placebo 6.1/1000-yr. HR } 2.1(95 \% \\
\text { CI, } 1.0-4.4)\end{array}$ & $\begin{array}{l}\text { Males: Canagliflozin: } \\
\text { 34.9/1000-yr vs placebo } \\
\text { 10.8/1000-yr }(\mathrm{P}<0.001) \\
\text { Females: Canagliflozin } \\
\text { 68.8/1000-yr vs placebo } \\
\text { 17.5/1000-yr }(\mathrm{P}<0.001)\end{array}$ & $\begin{array}{c}\text { Dapagliflozin } 76 / 8574 \\
(0.9 \%) \text { vs placebo } 9 / 8569 \\
(0.1 \%), P<0.001\end{array}$ & $\begin{array}{c}\text { Males: Empagliflozin 5\% vs } \\
\text { placebo } 1.5 \% \\
\text { Females: Empagliflozin } 10 \% \\
\text { vs placebo } 2.6 \%\end{array}$ \\
\hline $\begin{array}{l}\text { Acute renal } \\
\text { injury }\end{array}$ & $\begin{array}{c}\text { Canagliflozin } 16.9 / 1000 \text { patient-yr } \\
\text { vs placebo } 20.0 / 1000 \text { patient/yr, HR } \\
0.85 \text { (95\% CI, 0.64-1.13) }\end{array}$ & $\begin{array}{l}\text { Canagliflozin } 3.0 / 1000 \\
\text { patient-yr vs placebo } \\
4.1 / 1000 \text { patient-yr } \\
(\mathrm{P}=0.33)\end{array}$ & $\begin{array}{c}\text { Dapagliflozin } 1.5 \% \text { vs } \\
\text { placebo } 2 \% \text {. HR } 0.69(95 \% \\
\text { CI, } 0.55-0.87, P=0.002) .\end{array}$ & $\begin{array}{c}\text { eGFR }<60 \mathrm{ml} / \mathrm{min} / 1.73: \\
\text { Empagliflozin } 11.2 \% \text { vs } \\
\text { placebo } 14.3 \% \text { eGFR } \geq 60 \mathrm{ml} / \\
\text { min/1.73: Empagliflozin } 3.2 \% \\
\text { vs placebo } 3.9 \%\end{array}$ \\
\hline $\begin{array}{l}\text { Diabetic ketoac- } \\
\text { idosis }\end{array}$ & $\begin{array}{l}\text { Canagliflozin } 2.2 / 1000 \text { patient-yr vs } \\
\text { placebo } 0.2 / 1000 \text { patient-yr. HR } 10.8 \\
(95 \% \text { CI, } 1.39-83.6)\end{array}$ & $\begin{array}{l}\text { Canagliflozin } 0.6 / 1000-y r \\
\text { vs placebo } 0.3 / 1000-y r \\
\qquad P=0.14\end{array}$ & $\begin{array}{c}\text { Dapagliflozin } 27 / 8574 \\
(0.3 \%) \text { vs placebo } \\
12 / 8569(0.1 \%), \text { HR } 2.15 \\
(95 \% \text { CI, } 1.1-4.3), P=0.02\end{array}$ & $\begin{array}{c}\text { Empagliflozin } 4 / 4687(0.1 \%) \\
\text { vs placebo } 1 / 2333(<0.1 \%)\end{array}$ \\
\hline Amputation & $\begin{array}{c}\text { Canagliflozin } 12.3 / 1000 \text { patient-yr } \\
\text { vs placebo } 11.2 / 1000 \text { patient-yr. HR } \\
1.11(95 \% \text { CI, } 0.79-1.56)\end{array}$ & $\begin{array}{c}\text { Canagliflozin } 6.3 / 1000-y r \\
\text { vs placebo } 3.4 / 1000-y r, P \\
<0.001\end{array}$ & $\begin{array}{l}\text { Dapagliflozin } 1.4 \% \text { vs } \\
\text { placebo } 1.3 \%, P=0.53\end{array}$ & Not reported \\
\hline
\end{tabular}




\begin{tabular}{|c|c|c|c|c|}
\hline & & & Canagliflozin $15.4 / 1000-$ \\
Fractures & HR $0.98(95 \%$ CI $0.7-1.37)$ & $\begin{array}{c}\text { yr placebo } 11.9 / 1000- \\
\text { yr, P=0.02 }\end{array}$ & $\begin{array}{c}\text { Dapagliflozin 5.3\% vs } \\
\text { placebo 5.1\%, } \mathrm{P}=0.59\end{array}$ & $\begin{array}{c}\text { Empagliflozin 3.8\% vs placebo } \\
3.9 \%\end{array}$ \\
\hline
\end{tabular}

* HR: Hazard Ratio

\section{Candidate Patients for SGLT2 Inhibitors}

a) Based on the available data discussed above, SGLT2 inhibitors should be considered in the following situations: All patients with type 2 diabetes and albuminuric nephropathy with eGFR at baseline as low as $30 \mathrm{ml} / \mathrm{min} / 1.73 \mathrm{~m}^{2}$ on top of RAS blockers. This recommendation is based on results of the CREDENCE trial using canagliflozin $100 \mathrm{mg} / \mathrm{d}$ [3]. In fact, the subgroup of patients with eGFR 30 to $<45 \mathrm{ml} / \mathrm{min} / 1.73$ $\mathrm{m}^{2}$ represented $27 \%$ (1213 of 4401 ) of the study population [3]. The latter group of patients had similar benefits in terms of renal [3] and CV outcomes [11] to the remaining patients with higher eGFR. Furthermore, in CREDENCE trial, patients continued canagliflozin at much lower levels of eGFR until occurrence of ESKD and initiation of renal replacement therapy [3]. Accordingly, regulatory authorities should allow using canagliflozin $100 \mathrm{mg} / \mathrm{d}$ in patients with eGFR > $30 \mathrm{ml} /$ $\mathrm{min} / 1.73 \mathrm{~m}^{2}$ instead of the current cutoff of $45 \mathrm{ml} / \mathrm{min} / 1.73$ $\mathrm{m}^{2}$.

b) Patients with type 2 diabetes in general with or without albuminuria as renoprotective agents. This recommendation is based on the secondary outcomes of EMPA, DECLARE and CANVAS trials in which renal benefits in these $3 \mathrm{CV}$ trials were demonstrated in patients without albuminuria (70$93 \%$ of patients) or with albuminuria at baseline $(7-30 \%$ of patients) (Table 1).

c) In addition to the renoprotective effect, use of SGLT2 inhibitors was associated with significant decrease in CV events in patients with type 2 diabetes and established CV disease [15], those with multiple CV risk factors [16,17], and in those with heart failure and reduced ejection fraction whether or not they have diabetes [18].

\section{Conclusions and Future Directions}

SGLT2 inhibitors decrease renal events and slow progression of diabetic nephropathy in a wide spectrum of patients with type 2 diabetes. These agents should the standard of care in patients with type 2 diabetes thanks to their renal and CV benefits. Trials are underway to evaluate various SGLT2 inhibitors in patients with type 2 diabetes having CKD and eGFR as low as $20 \mathrm{ml} /$ $\mathrm{min} / 1.73 \mathrm{~m}^{2}$ [19]. Since the renal benefits of SGLT2 inhibitors are independent of their anti-hyperglycemic effects, these trials included patients without diabetes. If long-term safety and cardio-renal benefits of SGLT2 inhibitors are established, these drugs will replace metformin as initial drug of choice for type 2 diabetes and will likely change the ways of management of type 2 diabetes, CKD and heart failure.

\section{References}

1. Alicic RZ, Rooney MT, Tuttle KR (2017) Diabetic kidney disease: challenges, progress and possibilities. Clin J Am Soc Nephrol 12(12): 2032-2045.

2. Nasser (2014) Mikhail Place of sodium-glucose type 2 co-transporters inhibitors in treatment of type 2 diabetes. World J Diab 5(6): 854-859.

3. Perkovic V, Jardine MJ, Neal B, Bompoint S, Heerspink HJL, et al. (2019) Canagliflozin and renal outcomes in type 2 diabetes and nephropathy. N Engl J Med 380(24): 2295-2306.

4. Neal B, Perkovic V, Mahaffey KW, de Zeeuw D, Fulcher G, et al. (2017) CANVAS Program Collaborative Group. Canagliflozin and cardiovascular and renal events in type 2 diabetes. $\mathrm{N}$ Engl J Med 377(7): 644-657.

5. Mosenzon O, Wiviott SD, Cahn A, Rozenberg A, Yanuv l, et al. (2019) Effects of dapagliflozin on development and progression of kidney disease in patients with type 2 diabetes: analysis from the DECLARETIMI 58 randomized trial. Lancet Diab Endocrinol 7(8): 606-617.

6. Wanner C, Inzucchi SE, Lachin JM, Fitchett D, von Eynatten M, et al. (2016) Empagliflozin and Progression of Kidney Disease in Type 2 Diabetes. N Engl J Med 375(18): 323-334.

7. Neuen BL, Young T, Heerspink HJL, Neal B, Perkovic V, et al. (2019) SGLT2 inhibitors for the prevention of kidney failure in patients with type 2 diabetes: a systematic review and meta-analysis. Lancet Diab Endocrinol 7(11): 845-854.

8. Ingelfinger JR, Rosen CJ (2019) Clinical credence-SGLT2 inhibitors, diabetes, and chronic kidney disease. N Engl J Med 380(24): 23712372.

9. Holtkamp FA, de Zeeuw D, Thomas MC, Cooper ME, de Graeff PA, et al. (2011) An acute fall in estimated glomerular filtration rate during treatment with losartan predicts a slower decrease in long-term renal function. Kidney Int 80(3): 282-287.

10. Sarafidis P, Ferro CJ, Morales E, Ortiz A, Malyszko J, et al. (2019) SGLT2 inhibitors and GLP-1 receptor agonist for nephroprotection and cardioprotection in patients with diabetes mellitus and chronic kidney disease. A consensus statement by the EURECA-m and the DIABESITY working groups of the ERA-EDTA. Nephrol Dial Transplant 34(2): 208230 .

11. Mahaffey KW, Jardine MJ, Bompoint S, Cannon CP, Neal B, et al. (2019) Canagliflozin and cardiovascular and renal outcomes in type 2 diabetes mellitus and chronic kidney disease in primary and secondary cardiovascular prevention groups. Circulation 140(9): 739-750.

12. Mayer GJ, Wanner C, Weir MR, Inzucchi SE, Koitka-Weber, et al. (2019) Analysis from the Empa-Reg Outcome trial indicates empagliflozin may assist in preventing progression of chronic kidney disease in patients with type 2 diabetes irrespective of medications that alter intrarenal hemodynamics. Kidney Int 96(2): 489-504.

13. Manuyama T, Takasima H, Oguma H, Nakamura Y, Ohno M, et al. (2019) Canagliflozin improves erythropoiesis in diabetes patients with anemia of chronic kidney disease. Diab Techol Therap 21: 1-8.

14. Cherney DZ, Cooper ME, Tikkanen I, Pfarr E, Johansen OE, et al. (2018) Pooled analysis of phase III trials indicate contrasting influences of renal function on blood pressure, body weight, and $\mathrm{HbA} 1 \mathrm{c}$ reductions with empagliflozin. Kidney Int 93(1): 231-244. 


\section{Current Research in Diabetes \& Obesity Journal}

15. Zinman B, Wanner C, Fichett D, Bluhmki E, Hantel S, et al. (2015) Empagliflozin, cardiovascular outcomes, and mortality in type 2 diabetes. N Engl J Med 373(22): 2117-2128.

16. Wiviott SD, Raz I, Bonaca MP, Mosenzon O, Kato ET, et al. (2019) for the DECLARE-TIMI 58 Investigators. Dapagliflozin and cardiovascular outcomes in type 2 diabetes. N Engl J Med 380(4): 347-357.

17. Zelniker TA, Wiviott SD, Raz I, Im K, Goodrich IL, et al. (2019) SGLT2 inhibitors for primary and secondary prevention of cardiovascular and renal outcomes in type 2 diabetes: a systematic review and metaanalysis of cardiovascular outcome trials. Lancet 393(10166): 31-39.
18. McMurray JJV, Solomon SD, Inzucchi SE, Kober L, Kosiborod MN, et al. (2019) Dapagliflozin in patients with heart failure and reduced ejection fraction. N Engl J Med 381(21): 1995-2008.

19. Herrington WG, Preiss D, Haynes R, von Eynatten M, Staplin N, et al (2018) The potential for improving cardio-renal outcomes by sodiumglucose co-transporter-2 inhibition in people with chronic kidney disease: a rationale for the EMPA-KIDNEY study. Clin Kidney J 11(6): 749-761.

Your next submission with Juniper Publishers
will reach you the below assets
- Quality Editorial service
- Swift Peer Review
- Reprints availability
- E-prints Service
- Manuscript Podcast for convenient understanding
- Global attainment for your research
- Manuscript accessibility in different formats
( Pdf, E-pub, Full Text, Audio)
- Unceasing customer service
Track the below URL for one-step submission
https://juniperpublishers.com/online-submission.php

